\title{
GLOBAL HALAL INDUSTRY: REALITIES AND OPPORTUNITIES
}

\author{
Md. Siddique E Azam ${ }^{1 *}$, Moha Asri Abdullah ${ }^{2}$ \\ *Corresponding Author \\ ${ }^{1}$ International Institute for Halal Research and Training, International Islamic University Malaysia, \\ siddique77hstu@gmail.com \\ ${ }^{2}$ International Institute for Halal Research and Training, International Islamic University Malaysia, mosri@iium.edu.my
}

\begin{abstract}
The global Halal industry as a whole is estimated to worth around USD2.3 trillion (excluding Islamic finance) a year, is now one of the fastest growing markets. Simultaneously, the global market growth is estimated to reach at an annual rate of 20 percent per annum. The Halal industry is no longer confined to food and food-related products. This paper attempts to examine the current realities of the global halal industry by observing the factors determining such increasing demand for Halal industry in addition to the opportunities that are offered fromrecent global development in the market. To achieve the objectives of the study, a methodology of analyzing secondary data from different sources was adopted in this paper. The findings show that there are three major factors driving the rapidly growing global halal market. First, sizable and growing Muslim population at 1.8 per cent per annum, Second, growing economic development and hence increasing purchasing power among the Muslim. The last is the emergence of potential halal market in non-Muslim nations and halal industry players. As a way forward, industry players need to deepen knowledge and understanding of the Muslim market (pattern and behavior), regularly update data, and exploit untapped market niches as well as product sales and promotion. Findings and recommendations of this work will be a great resource for future researchers and scholars in relevant areas as well as policy makers to make their strategic decisions in the fields of Halal Industry.
\end{abstract}

Keywords: Driving factors, Global Halal Industry, Opportunity, Challenges

Received

February 16, 2020
Revised

March 27, 2020
Accepted

March 28, 2020
Published

March 31, 2020

\section{INTRODUCTION}

The halal market is no more limited to the boundary of food sector, rather it has extended its scope to include cosmetics and pharmaceuticals, toiletries and medical devices as well as service sector components such as logistics, marketing, print and electronic media, packaging, branding, and financing and so on. The global industry as a whole is estimated to worth around USD2.3 trillion (excluding Islamic finance) a year ("Global halal market Statistics \&amp; Facts | Statista," n.d.). The concept 'halal' also associates the concept 'Toyyib' meaning good. Thus, the meaning of 'halal' is anything which is permissible in Islam and good for human being. The integration of ethical values along with religious values opens up the boundary of halal industry from 2.8 billion Muslim consumer to non-Muslim consumer as well around the world. It is well accepted by non-Muslim consumers as a life style choice because of the values promoted by halal industry such as animal welfare, social responsibility, environment friendly, stewardship to earth, economic and social justice, and ethical investment(Pacific, 2010).Current Muslim population is 2.18 billion which is $28.26 \%$ of the total population is increasing at $1.84 \%$ a year ("Muslim Population in the World," n.d.). As the consumer size is increasing, the market size of halal industry is also increasing at an annual rate of $20 \%$ with a value of US $\$ 560$ billion a year (Pacific, 2010). Moreover, Muslim average per capita income (GDP) has risen from USD1763 to USD10,728 from 1993 to 2015 and the 57 OIC countries have a combined GDP of USD27.9 trillion ("Economy of 
the Organisation of Islamic Cooperation," Wikipedia, 2015).It seems that non-Muslim countries have realized the opportunities and potential growth of halal market and putting effort to lead in this sector of the world's economy. For example, Brazil, Australia, and Singapore are in the list of top ten countries with highest GIEI (Global Islamic Economy Indicator) score in halal food market in 2017-2018, although they are non-Muslim countries (Latif, 2017). In halal food industry, the largest market is meat and poultry which is, surprisingly, led by non-Muslim countries. New Zealand and Australia is leading worldwide in exporting halal meat. Brazil and Argentina, at the same time, are the biggest poultry producer (Nor Ai'han Mujar, 2015). While the Halal industry exhibits its' potential growth globally, Muslims lack awareness on Halal and the prospect of this industry (Yunos, et al, 2014). For all the Muslim countries, it is now the essence of time to identify and realize the opportunities and potentials of global halal market and occupy the leading positions worldwide. The awareness on the opportunities has to be made at all levels including government, academics, business entrepreneurs, corporate industries, policy makers, and as well as consumer level. Moreover, issues and challenges faced by halal industry should be identified and addressed by policy makers, researchers, academics, governments and respective authorities.

Thus, the purpose of this paper is to realize the current situation and prospects of global halal industry. It also investigates the factors that determines the rapid growth of global halal market. The final objective of the study is to address some of the issues and challenges in global halal market and provide recommendations accordingly. The findings of the study can be used to make awareness on the realities and opportunities of global halal market. Government and policy makers can use the results to develop policies and programs improving halal markets in respective countries.

\section{LITERATURE REVIEW}

The term 'halal' comes from the Arabic word namely halla, yahillu, hillan, wahalalanwhich means allowed or permissible by the Shariah law. According to Sharia'h law, every Muslim must ensure whatever they consume comes from a halal source. This confirmation shouldn't be limited to only ingredients but also the whole process of production and services (Zakaria 2008). Another study by Malboobi and Malboobi(2012), states some principles for halal and haram products. The study defines halal as lawful, beneficial, and not a serious threat or harm to human. Haram, on the other hand, was perceived as the opposite and the degree of being beneficial or harmful decides the ranks of shriah order based on the based on the subject on specific time, place, and necessity. The definition given by Jabatan Kemajuan Islam Malaysia (JAKIM), in Trade Description Order 2011, covers products and services encompassing all the business operations like packaging, marketing, manufacturing, logistic, supply, maintain premises, slaughtering and so on (JAKIM, 2015).

Realizing the significance of halal and its impact on the global economy, FAO (Food and Agriculture Organization) of United Nations has also prepared guidelines for using the term 'halal' to be adopted by its member countries (Ager, Abdullah et.al 2015). 


\section{Global Halal Industry}

The concept 'halal' which is not anymore confined to food only, has made the halal industry a new potential growth sector in the global economy. The industry is growing at 20 percent per year estimating a value of US $\$ 560$ billion and the total estimated value is US\$2.3 trillion. This value excludes Islamic Finance which also growing rapidly (Elasrag 2016). The industry is rapidly spreading its wing in the economy globally. It is no more limited to only 1.8 billion Muslims only, rather it is also the market for non-Muslims. Besides Malaysia, other countries like China, Thailand, Indonesia, Singapore, Korea, Philippine, and Australia have already tapped on the market. Many non-Muslim majority countries have realized the potential of the halal industry. In fact, some countries like Brazil, Australia, New Zealand, Italy, India, Germany are occupying the top ten positions in GIEI score in different halal sectors.

Figure 1. Market Share of Halal Industry Worldwide

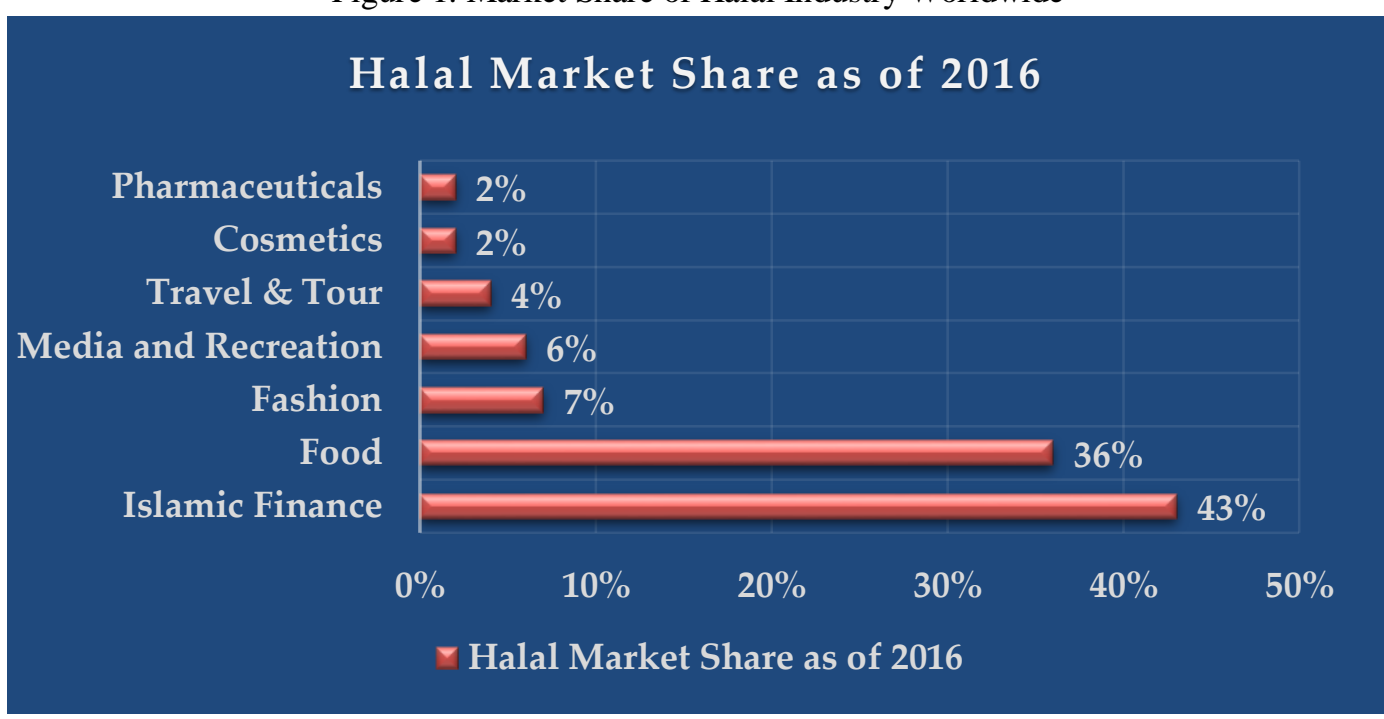

(Source:https://www.statista.com/topics/4428/global-halal-market/)

According to the study by Elasrag (2016), the halal Industry has extended not only its product sectors like pharmaceuticals, health products, toiletries, and cosmetics, but also in-service sectors like marketing, supply chain, logistic, packaging, manufacturing, branding, and financing. the study also implies that lifestyle offerings like travel \& tourism, hospitality management, and fashion industry are now also a major sector of extended halal industry.

Table 1. Potential Growth Sector

\begin{tabular}{|lc|}
\multicolumn{1}{|c|}{ Clusters } & $\begin{array}{c}\text { Potential Value for the Halal Market (USD) } \\
\text { (Based on 5\% of Global Halal Trade) }\end{array}$ \\
\hline Cosmetic / Personal Care & 177 Billion \\
\hline Agriculture & 41.5 Billion \\
\hline Pharmaceutical & 30.3 Billion \\
\hline Logistic & 25.0 Billion \\
\hline Islamic Finance & 0.17 Billion \\
\hline Travel Industry & 0.13 Billion \\
\hline $\begin{array}{l}\text { Total Value for Halal New } \\
\text { Growth Clusters }\end{array}$ & $\mathbf{2 7 4 . 1}$ Billion \\
\hline
\end{tabular}

Source: Halal Industry Development Corporation 
Study by Dar et. al. (2013) shows that the Muslim population has a growth rate of 3 percent per annum and constitute 23 percent of the world's population. Although some of the Muslim countries have higher purchasing power and a growing economy, rest of the countries, on the other hand have low par-capita income. The Third Industrial Master Plan; 2016-2020 of Malaysia indicates the aim of Malaysia to become the world's leading halal hub. In this regard the halal industry is projected to contribute about 5.8\% to the GDP of Malaysia. The global market is now following Malaysia and competing to be a global hub in halal industry.

\section{Opportunities and Driving Forces of Global Halal Market}

There are certain factors that drive the rapid growth of halal industry globally. These factors may include Muslim population around the world, GDP growth of Muslim countries, emerging halal markets, Muslim lifestyle offerings, and the growth of halal ecosystem. These driving forces, however, also indicate the underlying opportunities of halal industry in global economy. The following section identifies the mentioned factors as driving forces and shows the opportunities of global halal industry.

\section{Growing Muslim population}

The rapid growth of Muslim population around the world is the factor that driving the expansion of global halal market most. The global population is set to reach 8.3 billion and by the time Muslim population is projected to be 2.1 billion (Latif, 2017). However, recent data shows Muslim population already represents 28.26 percent of the world population which is 2.18 billion ("Muslim Population in the World," n.d.).

Millennial is also known as Generation Y, a driving factor in the growth of economy as well as global halal industry. It is them who address the needs of Muslim millennials and set the brands by bringing changes across retail economy. They are the driving force in terms of entrepreneurship, innovation, technology savvy, and potential strength. By 2027, Millennials are set to 2.8 billion of world's population as core consumer force. At the same time, Generation Y amongst the OIC countries will be reaching to 0.7 billion with an increasing average age 28.2 which is less than the age of global young population (Latif, 2017). As the fastest growing religion in terms of population, Islam is projected to be the most popular religion by 2070, which is another significant sign of halal industry growth (LIPKA, 2017).

\section{GDP Growth in Muslim Countries}

Gross Domestic Product by purchasing power parity or GDP (PPP) is another driving force of global halal industry growth and it is one of the economic tools to measure the potential strength of an economy. The definition of GDP (PPP) given by world bank is "the number of units of a country's currency required to buy the same amount of goods and services in the domestic market" compared to the United States market; based on the US dollar. As the size of population is growing, Muslim average per capita income (GDP) has risen from USD $\$ 1763$ to USD\$10,728 from 1993 to 2015 and the 57 OIC countries have a combined GDP of USD27.9 trillion (“Economy of OIC," Wikipedia, 2015). 
The purchasing power of Muslims as well as consumers around the world is also growing with the growing GDP of respective countries. Table 2 shows the GDP (PPP) of top 15 countries and their Muslim population.

Table 2. Top 15 Muslim Countries with Highest GDP (PPP) and Muslim Population

\begin{tabular}{|c|c|c|c|c|c|c|}
\hline \multirow{2}{*}{ Rank } & \multicolumn{4}{|c|}{ GDP (PPP) in US\$ Billion } & \multicolumn{2}{|c|}{ Population in Million } \\
\hline & Country & 2018 & 2019 & 2020 & Country & (2016) \\
\hline 1. & Indonesia & $3,498.80$ & $3,789.30$ & $4,103.30$ & Indonesia & 228.27 \\
\hline 2. & Saudi Arabia & $1,913.50$ & $2,015.60$ & $2,124.50$ & India & 265.78 \\
\hline 3. & Turkey & $1,828.30$ & $1,933.20$ & $2,043.70$ & Pakistan & 195.87 \\
\hline 4. & $\begin{array}{l}\text { Islamic Republic } \\
\text { of Iran }\end{array}$ & $1,641.00$ & $1,750.20$ & $1,866.30$ & Bangladesh & 149.87 \\
\hline 5. & Nigeria & $1,325.80$ & $1,421.20$ & $1,525.90$ & China & 137.8 \\
\hline 6. & Egypt & $1,193.20$ & $1,279.60$ & $1,372.90$ & Nigeria & 130.55 \\
\hline 7. & Pakistan & $1,123.40$ & $1,207.50$ & $1,297.70$ & Egypt & 88.83 \\
\hline 8. & Malaysia & 984.70 & $1,056.46$ & $1,133.20$ & Turkey & 79.34 \\
\hline 9. & $\begin{array}{l}\text { United Arab } \\
\text { Emirates }\end{array}$ & 743.00 & 786.70 & 834.40 & Iran & 78.71 \\
\hline 10. & Bangladesh & 740.90 & 810.00 & 883.30 & Ethiopia & 50.85 \\
\hline 11. & Iraq & 695.20 & 763.80 & 836.10 & Sudan & 40.84 \\
\hline 12. & Algeria & 671.30 & 710.50 & 751.10 & Algeria & 40.68 \\
\hline 13. & Kazakhstan & 499.70 & 532.05 & 568.05 & Iraq & 37.72 \\
\hline 14. & Qatar & 385.90 & 407.20 & 427.60 & Morocco & 34.35 \\
\hline 15. & Morocco & 329.00 & 353.8 & 381.0 & Afghanistan & 33.4 \\
\hline
\end{tabular}

Source:("List of Muslim Countries by GDP Purchasing Power Parity (2018-2020) - Materia Islamica," n.d.). http://www.muslimpopulation.com/

Global GDP, in PPP terms, is set to reach $\$ 168$ trillion with a growth rate of 5.8 percent in between 2016 and 2022. China, however, is already surpassing the US GDP in 2014. OIC countries, on the other hand, represented $\$ 18.3$ trillion in PPP terms which was 15.3 percent of the global economy in 2016. The 57 Muslim majority OIC countries are set to grow by 6.2 percent between 2016 and 2022 (Thomson Reuters Global Islamic Economy Report 2017/2018). The report also indicates China as the game changing player in the Islamic economy trade. The "One Belt One Trade" initiative of China involves 28 OIC countries and stands to benefit from $\$ 3$ trillion in infrastructure-related investments.

Export is also a major contributing component to the GDP of a country. Halal export is projected to surpass $\$ 1$ billion by 2030 from a total of $\$ 50$ million in 2016 . The export ecosystem of Halal industry is comprised of four components. Sustainable inventory, which is developed through animal import and breeding, shipped 0.5 tons per year. Then, advanced processing led by multinationals, employed over 5000. Third component is certification which is leading world-class Halal certification and accreditation. Finally, finance that makes funds available for SMEs (Thomson Reuters Global Islamic Economy Report 2017/2018). 


\section{Emergence of Halal Markets and Players}

In many countries around the world the industry players have a lot of campaign that creates indirect awareness on halal products and services that results Halal market force. Consumers around the world are becoming aware of the importance of Halal, not only in terms of food consumption, but also the ethical values integrated to it, e.g. Muslim friendly tourism (MFT), modest fashion, logistic, pharmaceuticals and many others. The trillion-dollar business in halal industry is the result of this emerging consumer need.

It is evident that Muslim majority countries like Malaysia, Indonesia, Saudi Arabia, and Pakistan and other non-Muslim countries are also leading in the GIE indicator score. However, the emerging markets in other countries like Thailand, Philippine, China, and Singapore show the potential growth in halal industry. The emerging markets of all these countries view halal as a means to stimulate the economy through exports, tourism, valueadd, trade, research, certification expertise, training programs, halal science symposium, raw material supplier and some other aspects (imarat Consultants, n.d.). Some examples of emerging new players include Singapore's supermarket MyOutlets, Japan's Nippon Express in logistic services, Turkey's Banvit meat company, U.K. based Willobrook Farm, Halal Exotic Meats, Asada's, HonestChop of U.S.A and many more.

Fleishman Hillard Majlis, 2011 in his book, "The New Silk Road", introduces China as a potential emerging halal market. The city, Yiwu, is one of the examples mentioned in the book where more than 200,00 Arab national visit every year as it is the largest wholesale consumer goods market in China. Realizing the scope of halal industry, few initiatives have been taken in the trading zone e.g. availability of products that appeal to Muslim consumers, convenient commerce, prayer hall for nearly 10,000 Muslims to pray, and easy access to halal foods.

U.S.A. is another potential emerging market in halal industry. Data, recently reported by imarat Consultants, n.d. shows that $16 \%$ of the consumers for US Kosher market are Muslim. For every 1 halal product in the shelves of supermarkets there are 86 Kosher products. It also states that, US Muslims are spending more than $\$ 16$ billion a year on Kosher products because halal products are not available there. Similar scenario can be observed in the UK halal market which is growing at $15 \%$ with a national average of $1 \%$ annually.

Moreover, countries around the world are emerging as market players competing each other in halal industry. A recent report by HDC, presented in Bio Malaysia \& ASEAN Bioeconomic Conference, 2015, states several such emerging markets globally. For example, UAE visioning to become the center of Islamic economy, domestic halal economy in China is increasing by $10 \%$ per annum, Thailand as the largest producer of halal processed foodvisioning to become the kitchen of the world, Japan foresees Halal as key source of contributor to its economy by 2020 , South Korea is visioning to become the main destination of halal tourism, and Brunei is visioning to become the Google for Halal (HDC, Bio Malaysia \& Asean Bioeconomy Conference, 2015).

\section{Muslim Lifestyle Offerings}

As the Muslim population is increasingly growing worldwide, halal industry has extended its offerings into lifestyle fields that include halal dining (ensuring halal food), Muslim friendly 
tourism and hospitality services, halal pharmaceuticals and cosmetics as well as fashion industry and entertainment (Figure 2).

Choice of Halal foods which is also quality and healthy is one of the greatest lifestyle offerings by halal industry for the Muslims as well as non-Muslim consumers. The demand of halal foods is increasing as the consumers are becoming aware of the halal integrity in terms of halal certification, halal standards, and halal raw materials. The food and beverage $(\mathrm{F} \& \mathrm{~B})$ sector are also the biggest sector in the industry occupying about $56 \%$ of the global Muslim spend across lifestyle sectors. Total Muslim spend in F\&B was \$1.24 Trillion in 2016 which is projected to reach $\$ 1.94$ Trillion by 2022 with a growth rate of 6.2 percent from previous year. There are significant opportunities for investment and creation of global halal foods as the sector is growing at nearly double that of global growth (Latif, 2017). The demand of food is expected to increase by more than $70 \%$ by 2050 which indicates a strong demand of halal food in future (Personal, Archive, Puah, Voon, \& Entebang, 2009).

Halal travel and Muslim friendly tourism is a new segment in halal service industry getting its moment in the sun. The demand exists in terms of halal meals on flight and hotels, halal airlines, Muslim friendly hotels and beaches and so on. According to the GIE report 2018 by Thomson Reuters, halal travelers are estimated to spend 12 percent or US\$169 billion of global market in 2016 with a growth rate of 11.8 percent from previous year. This value is forecasted to reach US $\$ 283$ billion by 2022 . Similar study presented by the Global Muslim Travel Index (GMTI) report 2017 shows spending by halal travelers in 2017 was US $\$ 155$ billion and the forecasted value by 2020 has been mentioned as US $\$ 300$ billion. Most of the Muslims are very much concern about in-flight halal meal when travelling for a long time. Middle east flight services are quite aware in this context to serve halal meals onboard departing from all major airports in the world which is deviated from the global trend. This has been continuously reported by the Centre for Aviation (CAPA) witnessing the growth and expansion rate of halal industry not seen in any other global market.

The beach resorts are an emerging market and potential opportunity in Halal travel. Personal et al. 2009 reviews the report "Salaam Gateway January 2016" and emphasizes the significance of this market. According to the report, the market is estimated of $\$ 250$ billion with a Muslim spending of $\$ 28$ billion in 2014. These beach resorts are targeting Muslim travelers by offering them halal foods, stay with no alcohol premises, dedicated prayer rooms, separate pools and fitness center and other Muslim friendly services addressing Muslim lifestyle needs. The report mentions 32 beach resorts in different countries like Turkey, Thailand, Maldives, Egypt, Jordan, Kuwait, and UAE that offer wide range of price levels, from budget to luxury.

One of the obvious expenses by Muslim travelers is for Hajj or Umrah which is the holy task performed by millions of Muslims every year. Potential opportunities prevail in the market of Hajj and Umrah. For example, launch of low-cost carriers by Malaysia Airlines in 2018, digital solution to perform Umrah al badal, introduction of hi-tech bracelets in Hajj safety push by Saudi Arabia, and many other market players.

Healthcare products and pharmaceuticals are also potential lifestyle offerings by halal industry which has shown impressive growth performance (Figure 2). There is a vast opportunity for this sector to tap into the global pharmaceutical industry which was worth $\$ 934.8$ billion in 2017 and will reach $\$ 1170$ billion in 2021 , growing at 5.8\%, according to a 
recent report by The Business Research Company (www.marketresearch.com). According to the Thomson Reuters report, halal certified vaccines for dengue fever, polio, and Meningococcal meningitis are soon to be launched worldwide. While gaining the traction in biologics and nutraceuticals, total Muslim in this area was $\$ 83$ billion in 2016 and projected to reach $\$ 132$ billion by 2022 .

Cosmetics and personal care are an integral component of lifestyle. Muslims are concern about the halal issues while using such products as the ingredients can be from non-halal sources. This awareness has made the Muslim consumers to demand halal cosmetics and personal care products more by spending $\$ 57$ billion in 2016 with a projection of $\$ 82$ by 2022 (Figure 2). However, there is a huge demand and supply gap in this sector globally, which is a great opportunity for halal industry to tap into. Currently, the supply of Halal cosmetics and personal care is only $18 \%$ of the total USD56 billion demand worldwide. Exporters globally are supplying only USD10 billion leaving a huge demand-supply gap estimated to be USD46 billion (HDC, Bio Malaysia \& Asean Bioeconomy Conference, 2015).

Figure 2Global Muslim Spend on Halal Life-Style Sectors(\$ Billion)

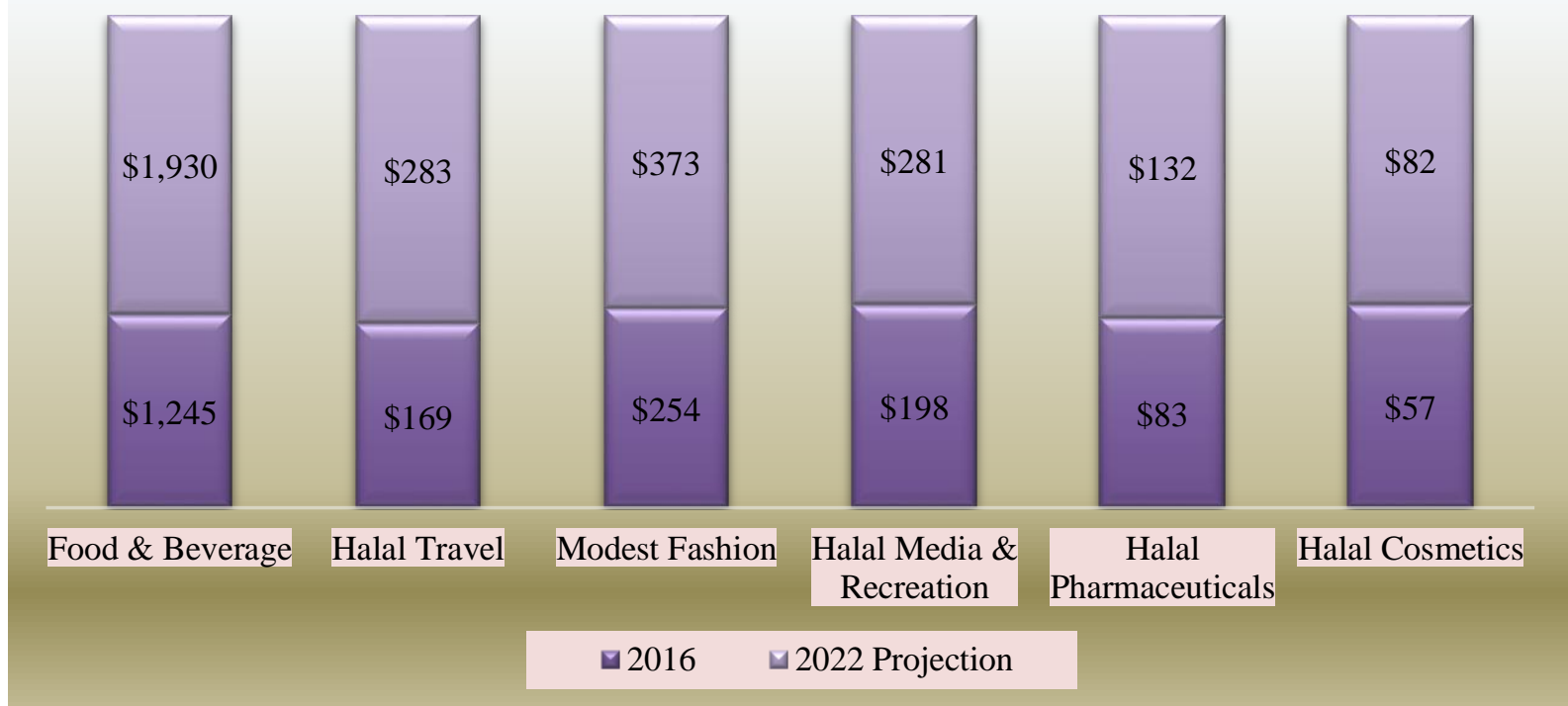

Source: Thomson Reuters Global Islamic Economy Report 2017/2018

Modest fashion, Media and Recreation is the segments of halal industry Targeting the Muslim millennial mainly. The clothing market is growing slowly offering trendy and modest athletic apparel, hijab, designer brands and boutiques, and Ramadan collection. The opportunity is realized by observing the spending of Muslims in fashion which was \$254 billion in 2016 and projected to reach $\$ 373$ billion by 2022 (Figure 2). Media and recreation are equally gaining traction and adapting to the needs of Muslim millennials especially. The industry is grabbing the market share by releasing new films and documentaries with Islamic content (Muslim culture, history, and life), new Islamic channels going on air, and streaming of many Islamic programs. By the year 2022 the Muslim spend is projected to reach $\$ 281$ billion from $\$ 198$ billion in 2016 (Figure 2).

Halal parks in different countries can play an important role in the ecosystem of halal industry creating opportunities in different ways. For example, in Malaysia, there are 21 halal 
parks serving 18 multinational companies with an employment of 5,274. Moreover, these halal parks involve more than 110 SMEs (Small and Medium Enterprises) and the investment is RM8.07 billion (Nor Ai'han Mujar, 2015).

The integrity of entire Halal supply chain is very important component for halal industry to take care the effective control of halal supply chain is more complex than traditional logistic operations. Certain Muslim markets around the world require different taste, packaging, distribution, and certification. Thus, adopting religious requirements in all these aspects of supply chain of halal ecosystem is becoming more profitable. For example, Meat \& Livestock Australia (MLA) has launched a halal brand for Australian meat in the middle East and Asia. Several Middle East Airlines and local freight forwarders are considering introducing specific Halal export logistics services with segregated handling and storage facilities. Japan's Nippon Express is offering halal food logistic services to meet the growing Asian demand. More evidence of the potential prospect of halal logistic includes Thai halal logistic programs. KosolSurinandha (head of Halal Logistics and Tourism at Chulaongkorn University) is leading a logistic program, Business Incubation for Halal Products (Bihap), that includes R\&D into new manufacturing techniques and logistic procedures to meet Halal export requirement (Catto-Smith, n.d.).

As the global demand of halal products increasing exponentially, the certifying bodies are expanding their scopes including testing, inspection, and certification services. Malaysia's JAKIM has extended Halal certification to prescriptive medicines in 2017. More than 100 export driven companies were certified in 2017 globally. Globally there are more than 350 certifiers with limited oversight and there were 27,000 certified organic operations globally in 2015. The International Halal Accreditation Forum (IHAF) of UAE, Dubai Islamic Economy Development Center (DIEDC), Emirates Authority for Standardization and Metrology (ESMA), and Standards and Metrology Institute for Islamic Countries (SMIIC) are some international bodies for certification and standard development (Thomson Reuters Global Islamic Economy Report 2017/2018).

\section{Challenges of Global Halal Industry}

While in one side, the Muslim consumers around the world represent a great opportunity for halal industry, on the other side, it is also a great challenge to deal with the diversity of the same population. Although the religious belief of Muslims is the same around the world, they have their own culture, regional or local shades, preferences, and practices. This is because Muslims live in every country of the world representing most of the races and come from every social and economic stratum (Personal et al., 2009).

The growing Muslim population and the growth of halal industry could be under threat by the non-Muslim population as well. The non-Muslim manufacturers, especially in the food and beverage industry. The unfriendly and malign act of introducing non-halal elements into foods, clothing, and other services claimed to be halal by the non-Muslim industry players poses a big challenge to the growth of halal industry globally. It may turn into a destructive threat as this intention of evil act by non-Muslims will decrease the halal integrity of the products and services and erode the confidence of the consumers (Personal et al., 2009).

One of the biggest challenges for Halal industry is establishing an internationally recognized halal standards and accreditation, especially in food sector. The recent act of banning Halal 
and Kosher slaughter in Denmark along with negative stories about Halal foods in the media is a warning to global halal industry. It is to ponder about the negative attitude prevalent in Europe and USA towards Halal and take challenges to remove such perceptions which is crucial for future success of Halal food sector (Thomson Reuters and Dinar Standard, 2016).

The challenge of establishing Halal standards and accreditation is also pivotal to remove confusion surrounding halal standards both in consumer and producer level. There's no international scheme to accredit Halal Certification Bodies (HCBs) in respective countries. Moreover, the standards are being produced by different government-linked organizations, private agencies and HCBs, national bodies, regional bodies, and as well as international bodies such as SMIIC (Standards and Metrology Institute for the Islamic Countries) or OIC initiative. Too many standards developing bodies create confusion to decide on which one will provide market access, and in many cases multiple certificates are necessary for exporters (Personal et al., 2009). Similar challenges were mentioned at Bio Malaysia \& Asean Bioeconomy Conference, 2015 stating a capacity and capability gap among the certification bodies.

The challenge of coming up with universal Halal standards also prevails in terms of preserving halal integrity throughout the supply chain and logistics management from farm to fork. Dedicated efforts, appropriate policies, standards, and procedures should be developed to ensure zero contamination to non-halal materials/ingredients along the supply chain. The lack of awareness and imbalance supply chain can be the barriers for halal industry development (Bio Malaysia \& Asean Bioeconomy Conference, 2015).

To be specific, the challenge lies in every sectors of Halal industry like food and beverage as mentioned earlier. For example, the Halal travel market faces challenges in terms of accommodation of both Muslims and non-Muslims in same hotel, lack of investment and shariah compliant funds, lack of common halal travel standards, dilemma in marketing, and no agreed definition of different terms used in the market e.g. Halal holiday, Muslimfriendly, and Family oriented hospitality (Personal et al. 2009, Thomson Reuters Report 2017/18).

The modest fashion, an emerging market segment in halal industry, with plenty of opportunities is also facing challenges. The regulations imposed by certain governmental agencies against religious attires put a big challenge for the industry to reach non-Muslim countries. other challenges in this sector include lack of marketing sophistication, lack of product innovation, and reluctance of investors to finance due to limited global success stories.

Halal media and recreation, another emerging market segment in the industry, that can experience substantial growth through multi-channel expansion, also holding risk and challenges at the same time to overcome. Unlike other sectors, getting financed and governmental support is a more promising challenge for this sector. The growth can also be hindered because of poor intellectual property (IP) rights that limits innovation as well as the sector to religious shows only. Diversification in cultural and religious themed shows and addressing the demand of young generations also add to the challenges in this sector (Thomson Reuters Report 2017/18).

As the Muslims are becoming concerned more and more about what they consume, a number of companies are offering pharmaceutical and cosmetic products that are free from animal 
sourced ingredients. However, the segment is not free from challenges either. Lack of halal ingredients availability, potential investors, limited standardization, and the fear of being limited to Muslim consumers only are some of the challenges the market is to face to ensure its growth globally. (Thomson Reuters Report 2017/18).

\section{METHOD}

To achieve the objectives of the study, a methodology of analyzing secondary data was adopted in this paper. The sources of all secondary data and information were extensive literature review, library search, a number of different websites, online journal publications, conference proceedings, thesis, different institutional reports and publications.

\section{RESULT AND DISCUSSION}

As the concept associated to 'toyyib', meaning good, and is applicable to all activities of human life, it has been observed from the literature and data from different sources that the Halal industry is spreading in every aspects of business and has become a potential growth sector globally. According to $6^{\text {th }}$ Halal Expo 2018, recently held in Turkey, global Halal market has a current volume of $\$ 4$ trillion (including Islamic finance) and is expected to reach $\$ 7$ trillion in three years. The growth of Halal industry is driven by certain forces which are the growing Muslim population size, GDP growth of Muslim countries, emerging halal markets and players, Muslim lifestyle offerings, and Halal ecosystem. While boosting the expansion of halal industry globally, these factors also are creating opportunities in every market segments of the economy.

Halal food sector has shown a significant achievement and Muslim spend continues to increase with a 6 percent growth from 2015. The potential opportunity in halal food and beverage sector is addressed by even non OIC countries. Halal food companies could be multi-billion dollar, publicly listed enterprises through trade finance, working capital and capital expansion. Halal food companies can also become halal lifestyle conglomerates through developing product categories and lines, and emerging dedicated halal free zones. Notable investment by different firms worldwide like Nestle, Janan Halal Meat, Kingsley etc. implies that Halal is becoming an area of focus for private equity firms.

In general, the industry is facing challenges in terms of standards recognized and adopted globally, research and development, innovations, alternative ingredients, and preserving Halal integrity throughout the supply chain management from farm to fork. Which is supported by the report published by Bio Malaysia \& Asean Bioeconomy Conference, 2015. The problem is being faced by the Halal industry from the very beginning is the absence of any viable international schemes to accredit Halal certification bodies (HCBs). It is the nonMuslim countries that produce a major part of the halal foods globally. To strengthen the accreditation of the independent HCBs in these countries, initiatives are being developed by SMIIC (Standards and Metrology Institute for the Islamic Countries), GSO (G.C.C. Standardization Organization), and ESMA (Emirates Standards and Metrology Authority).

\section{CONCLUSION}


The study was limited to secondary data and reviewing literature relevant to the Halal industry. The core challenge is the lack of harmonized standards which is holding back the industry causing confusion. Halal travel and tourism is one of the potential sectors of halal industry that can grow globally faster by identifying the relevant sectors and developing products accordingly. Products of both travel and other relevant sectors can be promoted to airlines. Effective system of standards like HOTREC Hotel stars Union and The Green Key Global are two successful examples for Halal travel industry to look into and realize the essence of unified global standards. Modest fashion companies need to appeal both Muslims and non-Muslims by embracing a broader consumer base. Besides focusing on quality, strong DNA, and workmanship, the industry should strategize policies of creating brand. This brand speaks the demand of modest fashion style of all demographics especially Muslim community. One more emerging market is Halal media and recreation where companies can grow through multi-channel expansion. The scope can be extended by shifting the focus beyond religious sectors. Diversification in cultural and religious themed media proposition can excel for significant minority population. The success of Alchemiya Media that raised over \$152,000 through crowd funding is a good example. However, government and investor involvement to facilitate the growth is necessary which a challenge for the industry. Other challenges for the industry include marketing to non-Muslim audiences and meeting the needs of millennials. All halal products produced in different countries and certified by different HCBs need more regulatory oversight. More coordination between the accreditation bodies is needed to avoid unnecessary duplication or competition. Future study may focus on in-depth exploring of specific segment of the Halal industry.

\section{REFERENCES}

Ager, S. N. S., et al. (2015). An Analysis of The Definition of Halal: Shari'ah Vs Statutes. World Academic and Research Congress 2015 (World-AR 2015) Ar-Rahim Hall, YARSI University, Jakarta, Indonesia.

Bio Malaysia \& Asean Bioeconomy Conference. (2015). Halal Economy: Opportunity and Challenges.

Retrieved

from http://biomalaysia.bioeconomycorporation.my/speakerssliders/day1/session2perlis/BioM alaysia 2015-v4(17.08.2015).pdf

Catto-Smith, C. (n.d.). THE WEEKLY LINK Halal logistics a fast-growing market. Retrieved from http://www.halalrc.org/images/Research Material/Literature/Halal logistics a fastgrowing market.pdf

Economy of the Organisation of Islamic Cooperation. (n.d.). Arabian Business. Retrieved from http://www.arabianbusiness.com/muslim-tourism-sector-said-be-worth-over138bn--growing-656633.html

Fleishman Hillard Majlis (2011). "The Market Opportunity of the Muslim World".

Global halal market - Statistics \&amp; Facts | Statista. (n.d.). Retrieved October 17, 2018, from https://www.statista.com/topics/4428/global-halal-market/

imarat Consultants. (n.d.). An Overview of the Global Halal Market South East Asia Driving the Halal. Media. Retrieved from http://www.halalrc.org/images/Research Material/Presentations/overview of global halal market.pdf

Jabatan Kemajuan Islam Malaysia. (2015). Manual Procedure for Malaysia Halal 
Certification (Third Revision) 2014. Manual Procedure for Malaysia Halal Certification (Third Revision) 2014, 67. https://doi.org/10.1017/CBO9781107415324.004

Latif, H. (2017). Outpacing The Mainstream: State of the Global Islamic Economy Report 2017/18. https://doi.org/10.1007/s00348-013-1600-9

LIPKA, M. (2017). Muslims and Islam: Key findings in the U.S. and around the world. Retrieved November 5, 2018, from http://www.pewresearch.org/facttank/2017/08/09/muslims-and-islam-key-findings-in-the-u-s-and-around-the-world/

List of Muslim Countries by GDP Purchasing Power Parity (2016-2020) - Materia Islamica. (n.d.). $\quad$ Retrieved $\quad$ November $\quad$ 2018, from http://materiaislamica.com/index.php/List_of_Muslim_Countries_by_GDP_Purchasing_ Power_Parity_(2016-2020)

Muslim Population in the World. (n.d.). Retrieved October 31, 2018, from http://www.muslimpopulation.com/

Malboobi, M. T. and M. A. Malboobi (2012). Halal concept and products derived from modern biotechnology. International workshop for Islamic scholars on agribiotechnology: Shariah compliance.

Nor Ai'han Mujar, N. H. (2015). The Economics of Halal Industry. Journal of Experimental Psychology: General, 136(1), 23-42.

Pacific, A. (2010). Global Halal Industry: An Overview. Global Islamic Finance Report 2013, 140-159. Retrieved from http://www.gifr.net/gifr2013/ch_13.PDF

Personal, M., Archive, R., Puah, C., Voon, S., \& Entebang, H. (2009). Halal Industry : key challenges dan Oppotunities, (10679).

Price level ratio of PPP conversion factor $(G D P)$ to market exchange rate. World Bank (The World Bank Group). Retrieved Nov $5^{\text {th }}, 2018$.

Pharmaceutical Drugs Global Market Report 2018, The Business Research Company, March 2018, retrieved fromhttps://www.marketresearch.com/Business-Research-Companyv4006/Pharmaceutical-Drugs-Global-Musculoskeletal-Disorder$11518658 /$ ?progid $=90731$

Yunos, R. M., Mahmood, C. F. C., \&Mansor, N. H. A. (2014). Understanding mechanisms to promote halal industry-the stakeholders' views. Procedia-Social and Behavioral Sciences, 130, 160-166.

Zakaria, Z. (2008). "Tapping into the world halal market: some discussions on Malaysian laws and standards." Shariah Journal 16(3): 603-616. 